\title{
Dorsetshire Numismatics; The Ancient Mints, with Notices of Some Medals Connected with the County
}

\section{Edward Hawkins Esq. F.S.A}

To cite this article: Edward Hawkins Esq. F.S.A (1866) Dorsetshire Numismatics; The Ancient Mints, with Notices of Some Medals Connected with the County, Archaeological Journal, 23:1, 122-130, DOI: $10.1080 / 00665983.1866 .10851342$

To link to this article: http://dx.doi.org/10.1080/00665983.1866.10851342

电 Published online: 11 Jul 2014.

Submit your article to this journal ¿ 
DORSETSHIRE NUMISMATICS; THE ANCIENT MINTS, WITH NOTICES OF SOME MEDALS CONNECTED WITH THE COUNTY.

From Notes communicatcd by EDWARD HAWKINS, Esq., F.S.A.1

IT has been customary, on several previous occasions, to bring together such notices as may be available relating to the ancient mints that existed in localities successively visited by the Institute in their Annual Meetings, and to invite attention to any subject of numismatic interest, associated either with the county which has been the special field of exploration, or the worthies of bygone times whose memory is there held in honor. Although the numismatic information to be obtained regarding Dorsetshire is almost as scanty as that which we were enabled last year to glean, on occasion of the meeting in Warwickshire, it is obviously desirable that, amidst numerous subjects of archæological attraction presented in the ancient territory of the Durotriges, the scattered facts familiar doubtless to the adept in numismatic science, and that relate to the local coinage in ancient times, should not be overlooked. It is moreover scarcely necessary to point out that, in tracing the history of the royal mints in any particular district, we are necessarily led to certain conclusions, not without general interest to the topographer, as tending to throw light on the relative importance of ancient towns there situated, and on their probable conditions in early times in regard to commercial relations and local industry.

There were four places in Dorset where coins were minted in early times-namely, Dorchester, Bridport, Shaftesbury, and Wareham. By the Laws of Exthelstan, who succeeded Edward the Elder in 924, and who appears to have been the first of the Anglo-Saxon monarchs that enjoined regulations for the coinage, it was ordained at the Synod at Greatanleage (probably Greatley, near Andover) that there should

1 This memoir was read at the Annual Meeting of the Institute at Durchester, July, 1865. 
be one money over all the ling's dominion, and that no man mint except within a town. ("butan on porte"). A certain number of moneyers were assigned for each place :- for London, 8 ; at Winchester, 6 ; at Wareham, 2 ; at Shaftesbury, 2 ; else, at the other "burhs" only one." Dorchester is not here specified; it may doubtless have been one of the towns ("burhs") at which a single moneyer was sanctioned. It must, however, be noticed that Leland, in an extract "ExDecretis Ethelstani," apparently from an ancient copy of the Anglo-Saxon Isaws, gives, after the two moneyers at Wareham, "In Dorcestra j." 3 No coin of Ethelstan struck at Dorchester appears to be known. In the Domesday Survey two moneyers are mentioned as there established in the reign of the Confessor." "In Dore Cestre tempore Regis Edwardi erant clxxij. domus. . . . Ibi erant ij. Monetarii, quisque eorum redd' regi unam mark' argenti, et $\mathrm{xx}$. solidos quando moneta vertebatur. Modo sunt ibi quater $\mathrm{xx}$. et viij. domus, et c. penitus destructæ." No coins struck at Dorchester are known to collectors earlier than the time of Ethelred II., who succeeded on the murder of Edward the Martyr at Corfe, A.D. 979. He appears to have had a mint at Dorchester, designated on his coins by the legend DoR. It is remarkable that, notwithstanding the large contributions exacted by the Danes in his reign, amounting to no less a sum, according to Florence of Worcester, than $167,000 l$. in various invasions, the last payment, in the year 1014, amounting to $30,000 l$, the monies of that reign, of common types, are by no means very rare : a fact to be attributed to the number of his mints far exceeding that of any preceding king. His moneyers were very numerous, and his laws, as Ruding points out, evince considerable attention to the preservation of the integrity of his money. ${ }^{5}$

The mints of King Cnut were likewise extremely numerous, and we find in his laws many ordinances relating to the coinage; the names of his moneyers are always placed upon his coins together with those of the mints. The coins struck at Dorchester are designated, as in the reign of

2 Lars of Aitbelstan, c. 14; Ancient I.aws and Institutes of England, vol. i. pp. 207, 209; Wilkins, p. 59; liuding, vol. i. p. 126.

3 Leland, Coll. vol. iii. p. 213.
4 Domesday Bork, vol. i. f. 75 a.

5 Laws of Asthelred. Ancient Laws and Institutes, vol. i. pp. 302, 303 ; Ruding, vol. i. p. 133 . 
Ethelred, by the legend Dor. There are many coins of the Conqueror struck at Dorchester, marked DORC-DORIDOREC-DORECES - DORCEST-DORCETR-DORECEST-DORTCET. The moneyers' names are Osbern, Wulfstan, Oter, Godwine, Lieric, and Lifric. A coin of that reign in the British Museum collection, and also in that in the Bodleian Library, inscribed SWIRTINC ON DORTH, may also be attributed to that place. ${ }^{6}$ In the large hoard of coins of the Conqueror found in 1833, at Beaworth, Hants, there were 25 of various types struck at Dorchester. ${ }^{7}$ There are likewise coins of William Rufus from the mint in that town. ${ }^{8}$

Bridport, as we learn from Domesday, had been a town of some importance before the Conquest: there was one moneyer there at that time. "In Brideport tempore Regis Edwardi erant cxx. domus . . . Ibi erat unus monetarius reddens regi j. mark' argenti, et $\mathrm{xx}$. sol. quando moneta vertebatur. Modo sunt ibi c. domus et xx. sunt ita destitutæ quod qui in eis manent geldam solvere non valent." ${ }^{9}$ In vain, however, had collectors searched for any example of money coined there until the discovery at Beaworth, Hants, before mentioned. ${ }^{1}$ Amongst the number of coins of William I. and William II. there were found on that occasion twelve struck at Bridport. ${ }^{2}$ The moneyers' names are BRIHTPI (Brihtwi ?) and IELFRIC or Alfric ; on Saxon money IE often occurs for $\mathbb{E}$, the diverging lines being somewhat irregularly introduced, thus II may be read either as A or V. The name of the town on the coins assigned to the Bridport mint is written BRD and BRIDI.

Shaftesbury appears to have been a place of even greater importance. In the enumeration of places where, according to the Laws of King सthelstan, moneyers were established, as before mentioned, two were ordained for Shaftesbury, ${ }^{3}$ and Edward the Confessor had three. The Domesday record is as follows:- "In Burgo Sceptesberie T. R. E. erant

6 Ibid., vol. ii. p. 163.

7 Seo Mr. Hawkins' Memoir, Archæologia, vol. xxvi. p. 10; Ruding, vol. i. p. 155 .

8 Ibid., p. 162.

- Vol. i. f. 75 a.

${ }^{1}$ A penny of Cnut is noticed by Ruding, vol. ii. p. 163, inscribed BRI, and which may, as he remarks, possibly have been struck at Bridport. It is, however, more probable that it was from the Bristol mint. He adds that no coins have yet been discovered that can be appropriated to the Bridport mint with certainty.

2 Archæologia, vol. xxvi. p. 8; liuding, vol. i. p. 154. The place of mintage of $t$ wo of the Beaworth coins, inscribed IELFrIC -BRIPVT, is considered as somewhat doubtful.

3 Ancient Laws and Institutes, vol. i. p. 209 . 
c. et iiij. domus in dominio regis . . . Ibi erant iij. monetarii, quisque reddebat j. mark' argenti, et $\mathrm{xx}$. solid. quando moneta vertebatur. Modo sunt ibi lxx. domus et lxxiij. sunt penitus destructe," \&c." Ruding includes this town in his list of mints of which coins are extant assigned to the reign of Ethelstan; the name being indicated by the legend SCEFT. ${ }^{5}$ No example, however, is preserved in the British Museum, and the existence of any such coin has not, as we believe, been ascertained. In the Museum collection coins minted at Shaftesbury are to be seen of the following kings :Fthelred II., Cnut, Edward the Confessor, Harold II., William I., and William II. The moneyers' names are Althestan, Goda, Elwig, Elwne, Lufa, Loda (possibly for Goda), Wulfric, Godric, Aelnod, Iilnod, Godsbran, Godsbrand, Godesbrand, Cinihtwine or Cihtwine. The town is indicated as Ceftan, Scefte, Scea, Sefte, Sceftesb, Scieft, Sciefti, \&c. Not less than 72 silver pennies of the reigns of William I. and William II. found in the great hoard at Beaworth have been ascribed to the mint of Shaftesbury. ${ }^{6}$

Ruding conjectured that Shaftesbury was indicated on coins of Henry III. by the legend SANTED-SEINTED or SENTED, as it was anciently called St. Edwardsbury,-Burgus Sancti Edwardi, - the coins minted at St. Edmundsbury being distinguished by the insertion of the letter Ir, thus SEDNVND, \&c. ${ }^{7}$

Wareham, which had two monetarii in the reign of Ethelstan, was a town of considerable importance from an early period. In Domesday we find the following record:"In Warham tempore Regis Edwardi erant cxliij. domus in dominio regis ... Ibi erant $\mathrm{ij}$. monetarii, quisque reddebat $j$. mark' argenti regi, et $\mathrm{xx}$. solid. quando moneta vertebatur. Modo sunt ibi lxx. domus et lxxiij. sunt penitus destructe," \&c. ${ }^{8}$ The sparing use of letters in the legends of early coins, always in very contracted form, renders it exceedingly difficult to determine with any certainty the

4 Domesday, vol. i. f. 75 a.

5 Ruding, vol. i. p. 127.

- Archæologia, vol. xxvi. p.13; Ruding, vol. i. p. 156. The coins inscribed scIE, with the moneyer's name cINInTPINE, have been assigned by Ruding to St. Idinondsbury, a place that had the privi-

VOL. XXIII. lege of coining in the reign of the Conqueror. As no other pennies occur in the Beaworth list that can be given to that place, Ruding's supposition may be correct.

7 Ruding, vol. ii. p. 163.

8 Jomesday, vol. i. f, 75 a. 
places where they were minted. veri occurring on a coin of \#thelstan has led collectors to assign it to Worcester, ${ }^{9}$ as well as to Wareham; we also, which is found upon a penny of Edwig, has been assumed by rarious numismatists as indicating either Wareham, Worcester, or Wallingford. WERE on coins of Ethelred II. has likewise been regarded as indicating the Wareham mint. Amongst the pennies of William I. and William II. found at Beaworth, as before noticed, there were not less than forty-five that may with strong probability be ascribed to Wareham; these coins bear the legends IEGELRIC ON WER, WERE, or WRE; IEGLRIC ON WERE, WERHE, ON WERHEI ; GODWINE ON WERE, OI WERI ; SIDELOC ON WERE, Or WERHE. ${ }^{1}$ The insertion of $\mathrm{H}$ in some of these names seems to support the supposition that they designate Wareham; and, as the moneyer Iegelric uses indiscriminately Wer, Were, Werhe, and Wre, to express, as it is believed, the name Wareham, it is probable that the more contracted forms $\mathrm{We}^{2}$ and Were, occurring on coins of other kings, may be taken as likewise denoting the mint of Wareham. Henry I. had a mint at that place, but Ruding was unable to trace it later than his reign. ${ }^{3}$

A remarkable medal commemorative of a Dorset Worthy claims notice on the present occasion, especially as associated with the name of our lamented friend the Earl of Ilchester, under whose auspices as President it had been our hope to have assembled in his county. This example of the artistic skill of the period, which it may be remembered was brought before the Institute by Lord Ilchester in 1856 and is noticed in this Journal, ${ }^{4}$ bears, on the obverse, the bust of Col. Strangways of Melbury, profile to the right, the hair long; the head uncovered, the neck bare; he is represented in armour, the lower part of the bust draped in a mantle. Legend, EGIDIVS. STRANGWAYS. DE . MELBVRY IN COM. DORCESTR. ARM., and, under the shoulder of the bust, IAN. R. F. Reverse, the White Tower, or Cæsar's Tower, London ; above is the sun breaking forth from a cloud, and shining on the Standard of England that floats from one of the corner turrets. Legend, DECVSQVE ADVERSA DEDERVNT. In

9 It has been thus given by Dr. Nash, the county historian, and by Mr. Green.

1 Archæologia, vol, xxvi. p. 14; Ruding, vol, i. p. 157 .
2 A coin of Cnut is thus marked; Ruding, vol. i. p. 138.

3 Ibid., vol. ii. p. 164.

- Arch. Journ, vol. xiii. p. 182. 
the exergue, INCARCERATVS SEPT. 1645. LIBERATVS APR. 1648. Diam. nearly 2 in. ${ }^{5}$ This fine medal is one of the works of John Rotier, whose signature JAN. R. appears on the obverse. The family came to England after the Restoration ; the father had assisted Charles II. in exile, and in retur'l the king promised, if he was restored, to employ his sons, who were gravers of seals and coins. Charles, on his return, dissatisfied with Simon, who had served Cromwell and the Commonwealth, sent for the brothers John and Joseph Rotier, and placed them at the Mint; the eldest, John, was in greatest repute. ${ }^{6}$ In Pepys' Memoirs a list of his principal productions may be found, with prices for which they were offered to him by Mr. Slingsby of the Mint, in $1687 .^{7}$ In this enumeration the Strangways Medal is valued at $1 l .17 \mathrm{~s}$. It is not of great rarity, and has generally been sold when in good condition for $5 l$. or $6 l$., though occasionally for a small price. It is to be seen in the British Museum collection, in the Hunter collection, and in several private cabinets. ${ }^{8}$ Two examples of gold are known.

This medal may probably be one of the supposed series struck in honor of those who suffered or distinguished themselves in the cause of Royalty. Giles Strangways was of one of the families of ancient note in Dorset; a pedigree may be seen in Hutchin's History of the County. He was born at the family seat, Melbury, in 1615. Early in the reign of Charles I. his father, Sir John Strangways, opposed the proceedings of the court, but, when he was convinced of the factious views of the party with which he had connected himself, and became dissatisfied with them for their violence against the Earl of Stafford, he attached himself to the royal party, and continued a faithful adherent to his king, for which he was honored by having his name inserted amongst those who were never to be pardoned. In the loyalty and consequent persecutions of his father, Giles Strangways

5 This medal has been figured by Evelyn; also in Pinkerton's Medallic History, pl. xviii. fig. 9, p. 54 ; and in Hutchins' History of Dorset.

6 Walpole's Anecdotes, Dallaway's edit., vol, iii. p. 187.

' Pepys' Correspondence, App. to his Diary edited by Lord Braybrooke, vol. v.

8 This medal has been sold for the following prices:-In $1774,6 l$. 6 s. at $\mathrm{Mr}$.
Selby's sale; 1775 , at $\mathrm{Mr}$. Oren's sale, 5l. 12s. 6d.; 1779, at Mr. Stacey's sale, 5l. 10s.; 1784, at Mr. Lindegreen's sale, $32.10 \mathrm{~s} . ;$ this last was sold again in 1790 for $1 l .7 \mathrm{~s}$.; in 1819 one sold for $5 l .7 \mathrm{~s} .6 \mathrm{~d}$. at Mr. Bindley's sale. All these were of silver. Mr. Browne of Shepton Mallet had one of gold; the late Mr. C. Wynue had also one of gold. 
largely partook; he commanded a regiment of horse in the West under Prince Maurice, and represented Bridport in Parliament, being disabled as member 22nd June, 1645. In August in that year he was fined 10,000l., and shortly afterwards was, with his father, imprisoned in the Tower. Upon payment of the moiety the father was to obtain his release, but the son was to remain till the full amount was liquidated. So much had this loyal family suffered that they were unable to discharge the fine; composition was refused, and both remained in prison till April, 1648, when upon acknowledging the fine they were liberated; the son, however, was confined to a distance of twenty miles from London, till the last instalment was paid, the time for which was extended to October 14, 1649. Both father and son were members of the convention parliament in 1660. Notwithstanding the distress to which the family had been reduced, and the pressure upon his finances which rendered a thirty months' imprisonment necessary, Colonel Strangways contrived to collect 300 broad pieces, which he sent to Charles II. whilst a fugitive after the battle of Worcester. Lloyd tells us that their loyalty cost this family at least 30,000l. Bishop Parker, in his Commentaries, gives a high character of Colonel Strangways in language to which translation can do inadequate justice :"Strangways, a man of ancient and illustrious family, eminent for the greatest opulence and loyalty. Through the entire war under Charles I. he was renowned for the utmost fortitude. He did and suffered for the ling every thing which a brave man could. Upon every occasion firm and steady in the strict line of duty, the intrepid and undaunted champion of the royal cause, even when it lay prostrate. Still was he extremely popular from the courteous affability of his manners towards every one, for which reason no one in his county was more valued, and by his influence the parliamentary elections were principally effected."

Of this loyal Dorsetshire gentleman there is a scarce portrait engraved by Loggan, to which are subjoined six lines, of which one, frequently quoted and frequently imitated, is as follows :- -

"None, but himself, himself can parallel." 
There is also a silver medal of the seventeenth century connected with Dorset, being in commemoration of the acquittal of the first Earl of Shaftesbury. $\mathrm{He}$ was born at Wimborne St. Giles, Dorset, July 22, 1621, and took an active part against Cromwell ; after the Restoration he was adranced to many positions of note; and was one of the most active statesmen of his times, the unflinching supporter also of the Protestant interest in England. Obverse, the bust of the Earl to the right; the hair is long; legend, ANTONIO COMITI DE SHAFTESBVRY; under the shoulder is the signature Q. B. F. (George Bower fecit). Reverse, a vierr of London, with London Bridge, the sun emerging from a cloud over the Tower. Legend, LETAMVR. In the exergue, 24 Nov. 1681. Diam. $1 \frac{5}{8}$ in. The Earl, falsely accused by one Bryan Hans, who pretended to make important revelations concerning the Popish plot and the murder of Sir Edmundbury Godfrey, was apprehended July 2, 1681 ; after being. examined by the king in council, he was committed to the Tower; his papers were searched, and the draught found, as alleged, of an "association" to exclude the Duke of York from the succession, and for treasonable violence towards Charles II. No evidence, however, of the Earl's participation in any such conspiracy being adduced, the Grand Jury, on the day mentioned on the medal, ignored the bill. There were rejoicings amongst the citizens, bonfires in the streets, and the bells rung for joy. ${ }^{9}$

George Bower is noticed by Walpole as "probably a volunteer artist," whose works were not numerous ; the best being the medal of the Earl of Shaftesbury. ${ }^{2}$

In the possession of the Bingham family, whose ancient lineage is held in honored remembrance in the county, a silver medal of Queen Anne is preserved, which, although not struck specially in connection with the county, cannot be regarded as undeserving of mention in these notices. It was presented to Richard Bingham, Esq., great-great-grandfather of our friend the Rev. C. W. Bingham, to whose kindly assistance and influence in lis county the Institute has often been under great obligations. The following record has been received with this medal, treasured as a family relic at Bingham's Melcombe :-

${ }^{9}$ Burnet; Collins, by Sir E. Brydges,
\&c.
1 Walpole's Anecdotes, ed. Dallaway, vol. iii. p. 193. 
"This Medal was given to Richard Bingham, Esq., my ever honoured Father, at the time it was struck, he being then Knight of the Shire of the County of Dorset, by the order of the Queen whose image and superscription it bears, and I desire and will that it shall for ever hereafter be esteemed and taken as an Heirloom, and descend to the Heirs of the Family of the Binghams who shall be entitled to the Capital Mansion House, Manor and Farm of Melcombe Bingham.

(Signed) "R. Bingham, 7th Jan. 1743."

The medal in question is that known to collectors as struck on the signing of the Treaty of Utrecht, March 30, 1713, and presented by the Queen's orders to the members of both Houses of Parliament. A medal of larger size (diam. $2 \frac{1}{4}$ in.) was struck for the Lords; a smaller one (diam. $1 \frac{3}{8}$ in.) for the Commons. The two medals are precisely similar, except in size; they were struck in England. The larger medal bears the signature I. c. (John Crocker)." Obverse, bust of Queen Anne to the left, with her usual titles. Reverse, on the left ships sailing on a calm sea, on the right husbandmen ploughing and sowing; in front, Britannia standing (on the larger medal), represented on the smaller as seated; a spear in her left hand, an olive-branch in her right. The legend is from Horace, Carm. lib. iv. Od. xiv. $\nabla .52,-$ COMIPOSITIS VENERANTVR ARMIS. In the exergue is the date MDCCXIII. ${ }^{3}$

The Dorsetshire series of small Tokens struck without authority "for necessary change," after the death of Charles I, is considerable. Snelling and other writers have described many of these small monies; Hutchins has figured a large number in his History of Dorset; a more ample inventory has been given by $\mathrm{Mr}$. W. Boyne, to which we may refer those who desire more precise information. 'The Dorset Tokens are chiefly farthings; the halfpennies are very few, and there are no pennies. Town-pieces were issued at Dorchester, Shaftesbury, and several other places enumerated by Mr. Boyne. Of these pieces several have been engraved for Hutchins' History of Dorset.

2 Medallist temp. William ILI., Aune, and George II. Walpole's Anecdotes, edit. Dallawny, vol, iii. p. 304 . See Mr. Pfister's account of Crocker, Num. Chron., vol. xv. p. $67 ; 1852$.

These two medals are engrared in
Tindal's Contin. of Rapin's Hist., vol. v. pl. ix. p. 19.

4 Tokens issued in the seventeenth century, described by W. Boyne, F.S.A., Lond, 1858, p. 61. 